GRASAS Y ACEITES 68 (2)

April-June 2017, e191

ISSN-L: 0017-3495

doi: http://dx.doi.org/10.3989/gya.0565161

\title{
Production of structured lipid with a low omega-6/omega-3 fatty acids ratio by enzymatic interesterification
}

\author{
H. Ilyasoglu \\ Gumushane University, Department of Nutrition and Dietetics, Baglarbası, 29100, Gumushane, Turkey \\ Correspondence: huriilyasoglu@yahoo.com, hilyasoglu@gumushane.edu.tr
}

Submitted: 19 May 2016; Accepted: 06 February 2017

SUMMARY: A structured lipid (SL) constituting omega fatty acids was synthesized by using linseed and grape seed oils as substrates via a lipase-catalyzed reaction. Lipozyme ${ }^{\circledR}$ TL IM was used as a biocatalyst. Good quadratic models predicting the incorporation of omega fatty acids were achieved via the Response surface methodology (RSM). The optimal conditions for targeted omega-6/omega-3 fatty acid ratio (2:1) were obtained at

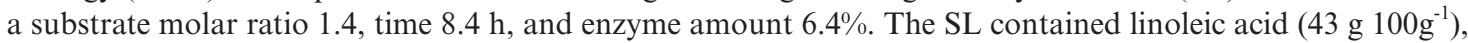

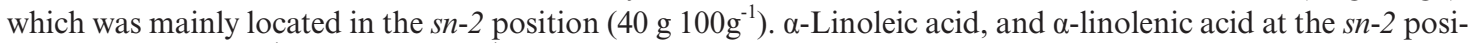

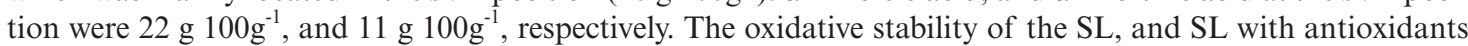
was also investigated. The produced SL may be proposed as a source of a balanced intake of omega fatty acids and an ingredient in functional food formulations.

KEYWORDS: Enzymatic interesterification; Omega-3; Omega-6; Oxidative stability; Structured lipid

RESUMEN: Producción de lípidos estructurados con una baja relación de ácidos grasos omega-6lomega-3 mediante interesterificación enzimática. Se sintetizaron lípidos estructurados (SL), formados por ácidos grasos omega, utilizando aceites de linaza y semillas de uva como sustratos a través de una reacción catalizada por lipasa. Se utilizó Lipozyme ${ }^{\circledR}$ TL IM como biocatalizador. Los buenos modelos cuadráticos que predecían la incorporación de los ácidos grasos omega se lograron a través de la metodología de superficie de respuesta (RSM). Se obtuvieron las condiciones óptimas para una proporción de ácidos grasos omega-6/omega-3 (2:1) con una relación molar de sustrato 1:4, tiempo de 8,4 h, y cantidad de enzima 6,4\%. El SL contenía ácido linoleico $\left(43 \mathrm{~g} \cdot 100 \mathrm{~g}^{-1}\right)$, que se localizaba principalmente en la posición sn-2 $\left(40 \mathrm{~g} \cdot 100 \mathrm{~g}^{-1}\right)$. El ácido $\alpha$-linoleico y el ácido $\alpha$-linolénico en la posición sn-2 fueron de $22 \mathrm{~g} \cdot 100 \mathrm{~g}^{-1}$ y $11 \mathrm{~g} \cdot 100 \mathrm{~g}^{-1}$, respectivamente. También se investigó la estabilidad oxidativa del SL y SL con antioxidantes. El SL producido puede ser propuesto como una fuente para una ingesta equilibrada de ácidos grasos omega y un ingrediente en las formulaciones de alimentos funcionales.

PALABRAS CLAVE: Estabilidad oxidativa; Interesterificación enzimática; Lípido estructurado; Omega-3; Omega-6

ORCID ID: İlyasoğlu H http://orcid.org/0000-0001-5710-2954

Citation/Cómo citar este artículo: Ilyasoglu H. 2017. Production of structured lipid with a low omega-6/omega-3 fatty acids ratio by enzymatic interesterification. Grasas Aceites $\mathbf{6 8}$ (2), e191. http://dx.doi.org/10.3989/gya.0565161

Copyright: (C2017 CSIC. This is an open-access article distributed under the terms of the Creative Commons Attribution (CC-by) Spain 3.0 License. 


\section{INTRODUCTION}

Omega fatty acids are known to show beneficial and protective effects against diseases. Omega-3 fatty acids may reduce the risk of cancer and heart diseases. Omega-6 fatty acid deficiency in a diet may cause scaly dermatitis, impaired growth and poor wound healing. A balanced ratio of these fatty acids is important to prevent chronic diseases. A lower ratio may be suggested to improve general health and to minimize the risk of disease. The optimal recommended ratio of omega-6/ omega-3 fatty acids for meeting the body's requirements and promoting health should be in the range of 1-4:1 (Gomez-Candela et al., 2011; Göğüss and Chris, 2010).

Linoleic acid is the parent fatty acid of omega- 6 fatty acids, while the parent fatty acid of omega-3 fatty acids is $\alpha$-linolenic acid. Sunflower, corn and soybean oils, the most consumed oils, are rich in linoleic acid (Simopoulus, 2008). The consumption of these oils increases the intake of omega- 6 fatty acids and results in a high omega-6/omega- 3 fatty acid ratio in the human diet. Numerous studies showed that the ratio of omega-6/omega-3 fatty acids in the human diet is very high (15:1). Therefore, omega-3 fatty acids in the human diet should be increased (Gomez-Candela et al., 2011). The enzymatic modification of oils may be one solution to reduce the omega-6/omega-3 fatty acid ratio in the human diet. As far as we know, oils can be enriched with omega-3 fatty acids via lipase-catalyzed reactions (Hamam and Shahidi, 2005a; Hita et al., 2007; Rao et al., 2006; Shimada et al., 1999). A structured lipid (SL) with a low ratio of omega-6/omega-3 fatty acids may be synthesized by enzymatic reactions. Perilla oil with soybean oil (Mitra et al., 2010a), linseed oil with groundnut oil (Sharma et al., 2009), soybean and corn oil with perilla oil (Mitra et al., 2010b), soybean oil with sardine oil (Araujo et al., 2011), and grape seed and perilla oil (Yang et al., 2013) have been used to produce SL with a low ratio of omega-6/omega-3 fatty acids.

Grape seed oil is rich in omega- 6 fatty acids, mainly linoleic acid $\left(>50 \mathrm{~g} \cdot 100 \mathrm{~g}^{-1}\right)$, whereas linseed oil contains omega- 3 fatty acids, mainly $\alpha$-linolenic acid $\left(>50 \mathrm{~g} \cdot 100 \mathrm{~g}^{-1}\right)$. They may be used to synthesize SL with a low ratio of omega-6/omega-3 fatty acids by means of an enzymatic reaction. There is no available study on the development of SL with a low ratio of omega-6/omega-3 fatty acids using grape seed and linseed oils. Therefore, the purpose of the present study was to produce SL with a balanced ratio of omega-6/omega-3 fatty acids by using linseed oil (as a source of $\alpha$-linolenic acid) and grape seed oil (as a source of linoleic acid) via a lipase-catalyzed reaction. The effect of the reaction conditions on the fatty acid composition was investigated by means of response surface methodology (RSM). The chemical properties and oxidative stability of the synthesized SL were also determined.

\section{MATERIALS AND METHODS}

\subsection{Materials}

Linseed and grape seed oils were supplied by the Origo Company (Gaziantep, Turkey). Tripalmitin, and pancreatic lipase were purchased from SigmaAldrich. Lipozyme ${ }^{\circledR}$ TL IM was donated by Novo Nordisk A/S (Bagsvaerd, Denmark). Organic solvents and TLC plates were obtained from Merck Co. (Darmstadt, Germany).

\subsection{Experimental design}

A three-factor and three-level central composite design was used for the RSM study. Table 1 shows the experimental design. Substrate molar ratio (grape seed oil/linseed oil), (1-3 mol:mol); time (h), (6-24 h); and enzyme amount (E\%), (3-15\% of total weight of substrates) were chosen as factors to perform the RSM study.

The experimental design and data analysis were carried out using Modde 10.1 software (Umetrics, Sweden).

\subsection{Enzymatic interesterification reaction}

The reaction mixture consisting of substrate oils and enzyme was weighed in a screw-cap reaction tube $(20 \mathrm{~mL})$, and the test tube was placed in an orbital shaking water bath at $200 \mathrm{rpm}$ at $60{ }^{\circ} \mathrm{C}$ (Daihan, South Korea). At the end of the reaction, the product was filtered to remove enzyme and then stored at $-18^{\circ} \mathrm{C}$ until analysis.

\subsection{Purification of SLs}

The SL was purified in accordance with a method described by Araujo et al. (2011) with some modifications. Alcoholic potassium hydroxide $\left(0.8 \mathrm{~mol} \cdot \mathrm{L}^{-1}\right.$, $5 \mathrm{~mL}$ ) was added to the product dissolved in hexane $(7.5 \mathrm{~mL})$. They were mixed, and the phases containing FFAs and TAGs were decanted. The hydro-alcoholic phase was extracted with twice hexane $(1.25 \mathrm{~mL})$. The collected hexane phases were evaporated. TLC identification of the free fatty acids and acylglycerols showed that free fatty acids were effectively separated.

\subsection{Chemical properties}

Free fatty acids (AOCS Ca 5a-40), peroxide value (AOCS Ja 8-87), saponification value (AOCS Da 16-48) and iodine value (AOCS Da 15-48) of the substrates and the products were determined in accordance with the official methods of the AOCS (2006). 
TAble 1. Central Composite Design Arrangement with Levels of Factors and Linoleic Acid and $\alpha$-Linolenic Acid Incorporation

\begin{tabular}{lccccccc}
\hline $\begin{array}{l}\text { Experiment } \\
\text { No }\end{array}$ & $\begin{array}{c}\text { Substrate molar } \\
\text { ratio (mol/mol) }\end{array}$ & $\begin{array}{c}\text { Time (h) } \\
X_{2}\end{array}$ & $\begin{array}{c}\text { Enzyme amount } \\
\left(\mathbf{g} \cdot \mathbf{1 0 0} \mathbf{g}^{-1}\right) \\
X_{3}\end{array}$ & $\begin{array}{c}\text { Linoleic acid } \\
\left(\mathbf{g} \cdot \mathbf{1 0 0} \mathbf{g}^{-1}\right) Y_{1} \\
(\mathbf{O b s e r v e d})\end{array}$ & $\begin{array}{c}\text { Linoleic acid } \\
\left(\mathbf{g} \cdot \mathbf{1 0 0} \mathbf{g}^{-1}\right) Y_{1} \\
(\text { Predicted) }\end{array}$ & $\begin{array}{c}\alpha-\text { Linolenic acid } \\
\left(\mathbf{g} \cdot \mathbf{1 0 0} \mathbf{g}^{-1}\right) Y_{2} \\
(\text { Observed) }\end{array}$ & $\begin{array}{c}\alpha-\text {-Linolenic } \\
\mathbf{a c i d}\left(\mathbf{g} \cdot \mathbf{1 0 0} \mathbf{g}^{-1}\right) \\
Y_{2}(\text { Predicted) }\end{array}$ \\
\hline 1 & $1(-1)$ & $6(-1)$ & $3(-1)$ & 37.3 & 36.9 & 25.1 & 24.4 \\
2 & $1(-1)$ & $24(1)$ & $15(1)$ & 33.7 & 34.9 & 22.1 & 22.9 \\
3 & $3(1)$ & $6(-1)$ & $15(1)$ & 47.8 & 46.9 & 12.5 & 12.3 \\
4 & $3(1)$ & $24(1)$ & $3(-1)$ & 42.2 & 44.9 & 10.8 & 11.5 \\
5 & $2(0)$ & $15(0)$ & $9(0)$ & 42.5 & 43.6 & 15.5 & 15.8 \\
6 & $1(-1)$ & $6(-1)$ & $15(1)$ & 36.3 & 36.9 & 24.3 & 24.1 \\
7 & $1(-1)$ & $24(1)$ & $3(-1)$ & 37.7 & 34.9 & 24.4 & 23.2 \\
8 & $3(1)$ & $6(-1)$ & $3(-1)$ & 48.3 & 46.9 & 12.9 & 12.7 \\
9 & $3(1)$ & $24(1)$ & $15(1)$ & 46.5 & 44.9 & 11.8 & 11.1 \\
10 & $2(0)$ & $15(0)$ & $9(0)$ & 42.2 & 43.6 & 15.1 & 15.8 \\
11 & $1(-1)$ & $15(0)$ & $9(0)$ & 34.4 & 35.9 & 22.3 & 23.6 \\
12 & $3(1)$ & $15(0)$ & $9(0)$ & 44.7 & 45.9 & 11.6 & 11.9 \\
13 & $2(0)$ & $6(-1)$ & $9(0)$ & 44.4 & 44.6 & 16.2 & 16.4 \\
14 & $2(0)$ & $24(1)$ & $9(0)$ & 43.9 & 42.6 & 15.9 & 15.2 \\
15 & $2(0)$ & $15(0)$ & $3(-1)$ & 43.5 & 43.7 & 15.5 & 16.0 \\
16 & $2(0)$ & $15(0)$ & $15(1)$ & 44.5 & 43.6 & 16.1 & 16.0 \\
17 & $2(0)$ & $15(0)$ & $9(0)$ & 44.5 & 43.6 & 16.2 & 15.8 \\
\hline
\end{tabular}

\subsection{Fatty acid composition}

The determination of the fatty acid composition was performed in accordance with the AOAC official method Ce 1f-96 (2006). The fatty acid methyl esters (FAMEs) were injected into a Shimadzu GC-2010 Plus gas chromatograph equipped with a flame ionization detector, a split/splitless injector and a long capillary column $(0.25 \mathrm{~mm}$ x $0.20 \mu \mathrm{m}$ x $60 \mathrm{~m}$, Teknokroma, Spain). The carrier gas was nitrogen at a flow rate of $60 \mathrm{~mL} \cdot \mathrm{min}^{-1}$. The oven program was: $1^{\text {st }}$, The initial temperature was $90^{\circ} \mathrm{C}, 2^{\text {nd }}$, Isothermal heating at $90^{\circ} \mathrm{C}$ for $5 \mathrm{~min}, 3^{\text {rd }}$, A ramp with $10^{\circ} \mathrm{C} / \mathrm{min}$ to $240^{\circ} \mathrm{C}, 4^{\text {th }}$, Isothermal heating at $240^{\circ} \mathrm{C}$ for $20 \mathrm{~min}$. The identification of FAMEs was performed using a standard FAME reference mixture (Supelco, Bellefonte PA, USA).

\section{7. $S n-2$ positional fatty acids}

Sn-2 positional fatty acids were detected using a method described by Hamam and Shahidi (2005b).

\subsection{Oxidation study}

The oxidative stability of the SL, and SL with antioxidants (BHT: $200 \mathrm{mg} \cdot \mathrm{kg}^{-1}$, BHA: $200 \mathrm{mg} \cdot \mathrm{kg}^{-1}$, rosemary extract: $200 \mathrm{mg} \cdot \mathrm{kg}^{-1}$ ) was evaluated via the Schaal oven test. The antioxidant dissolved in ethanol was added to the test tube including $1 \mathrm{~g}$ of the SL, and the test tubes were stirred in an ultrasonic bath. The sampling from the open test tubes stored at $60^{\circ} \mathrm{C}$ was performed at the beginning and then on the $1^{\text {st }}$, $2^{\text {nd }}, 4^{\text {th }}$ and $6^{\text {th }}$ days. Peroxide value $(\mathrm{PV}), p$-anisidine (p-AV) and TBARS values were determined using the official methods of the AOCS Ja 8-87, AOCS Cd 18-90 and AOCS Cd 19-90, respectively.

Total oxidation (TOTOX) value was calculated in accordance with the following formula:

TOTOX $=(2 \mathrm{PV})+(p-\mathrm{AV})$

\subsection{Scale-up production}

At the optimal conditions, a batch reaction (25 times scale-up) was performed to validate the reaction.

\subsection{Statistical analyses}

The regression analyses, statistical significance, analysis of variance (ANOVA), and response surfaces were analyzed via Modde 10.1 software (Umetrics, Sweden). The analysis was done in triplicate, and mean values and standard deviations were calculated.

\section{RESULTS AND DISCUSSION}

\subsection{Fatty acid composition}

It can been seen from Table 2 that the linseed oil contained $52 \mathrm{~g} \cdot 100 \mathrm{~g}^{-1}$ of $\alpha$-linolenic acid, $24 \mathrm{~g} \cdot 100 \mathrm{~g}^{-1}$ of oleic acid, and $14 \mathrm{~g} \cdot 100 \mathrm{~g}^{-1}$ of linoleic acid as 
the main fatty acids, while grape seed oil included $63 \mathrm{~g} \cdot 100 \mathrm{~g}^{-1}$ of linoleic acid, $19 \mathrm{~g} \cdot 100 \mathrm{~g}^{-1}$ of oleic acid and $13 \mathrm{~g} \cdot 100 \mathrm{~g}^{-1}$ of palmitic acid. Oleic $\left(43 \mathrm{~g} \cdot 100 \mathrm{~g}^{-1}\right)$, linoleic $\left(18 \mathrm{~g} \cdot 100 \mathrm{~g}^{-1}\right)$, and $\alpha$-linolenic acid $\left(34 \mathrm{~g} \cdot 100 \mathrm{~g}^{-1}\right)$ were the major fatty acids at the $s n-2$ position in the linseed oil. The grape seed oil contained oleic $\left(34 \mathrm{~g} \cdot 100 \mathrm{~g}^{-1}\right)$, and linoleic acid $\left(59 \mathrm{~g} \cdot 100 \mathrm{~g}^{-1}\right)$ as the main fatty acid at the $s n-2$ position.

\subsection{Model fitting}

Structured lipid (SL) containing omega fatty acids was produced by the lipase-catalyzed reaction of the linseed and grape seed oils. A 3-factor and 3-level central composite design (CCD) was performed to optimize the reaction conditions. Table 1 shows the independent variables $\left(X_{l}\right.$ : substrate molar ratio, $X_{2}$ : time, and $X_{3}$ : enzyme amount) and the responses $\left(Y_{1}:\right.$ linoleic acid and $Y_{2}: \alpha$-linolenic acid). The regression coefficients and $p$-values of the final models by the multiple regression analysis for omega fatty acids are presented in Table 3 . The enzyme amount $\left(X_{3}\right)$, which was a non-significant factor ( $p>0.10$ ), could be retained in the model since it increased the quality of fit. The response model equations for the omega fatty acids can be written as follows:

$Y_{1}=43.64+5.01 X_{1}-2.75 X_{1}^{2}-1.01 X_{2}-0.02 X_{3}$

$Y_{2}=15.79-5.86 X_{1}+1.99 X_{1}^{2}-0.60 X_{2}-0.19 X_{3}$

The most significant factor was $X_{I}(\mathrm{p}<0.001)$ followed by $X_{1}^{2}(\mathrm{p}<0.01), X_{2}(\mathrm{p}<0.10)$ and $X_{3}$ $(\mathrm{p}>0.10)$. The linear term of substrate molar ratio exhibited positive influence on the linoleic acid, whereas it had negative influence on the $\alpha$-linolenic acid. The linoleic acid was negatively influenced by the quadratic effect of substrate molar ratio, whereas $\alpha$-linolenic acid was positively affected. The linear terms of time and enzyme showed negative influence on both fatty acids.

TABLE 2. Fatty Acid Composition of Linseed and Grapeseed Oil, and SL Produced under Optimal Conditions

\begin{tabular}{|c|c|c|c|c|c|c|}
\hline \multirow[b]{2}{*}{$\begin{array}{l}\text { Fatty } \\
\text { Acids }\end{array}$} & \multicolumn{2}{|c|}{ LO } & \multicolumn{2}{|c|}{ GO } & \multicolumn{2}{|c|}{ SL } \\
\hline & $\begin{array}{c}\text { Fatty acid } \\
\left(\mathrm{g} \cdot 100 \mathrm{~g}^{-1}\right)\end{array}$ & $\begin{array}{l}\text { Fatty acid at sn-2 } \\
\left(\mathrm{g} \cdot 100 \mathrm{~g}^{-1}\right)\end{array}$ & $\begin{array}{l}\text { Fatty acid } \\
\left(\mathrm{g} \cdot 100 \mathrm{~g}^{-1}\right)\end{array}$ & $\begin{array}{c}\text { Fatty acid at sn-2 } \\
\left(\mathrm{g} \cdot 100 \mathrm{~g}^{-1}\right)\end{array}$ & $\begin{array}{c}\text { Fatty acid } \\
\left(\mathrm{g} \cdot 100 \mathrm{~g}^{-1}\right)\end{array}$ & $\begin{array}{l}\text { Fatty acid at sn-2 } \\
\left(\mathrm{g} \cdot 100 \mathrm{~g}^{-1}\right)\end{array}$ \\
\hline $\mathrm{C} 14: 0$ & ND & ND & $0.24 \pm 0.01$ & $0.13 \pm 0.01$ & $0.14 \pm 0.01$ & $0.18 \pm 0.05$ \\
\hline $\mathrm{C} 16: 0$ & $5.62 \pm 0.01$ & $2.83 \pm 0.05$ & $12.75 \pm 0.01$ & $4.55 \pm 0.15$ & $9.51 \pm 0.25$ & $7.93 \pm 0.43$ \\
\hline $\mathrm{C} 16: 1$ & $0.10 \pm 0.01$ & $0.15 \pm 0.01$ & $0.22 \pm 0.01$ & $0.26 \pm 0.01$ & $0.17 \pm 0.01$ & $0.24 \pm 0.02$ \\
\hline C18:0 & $3.64 \pm 0.01$ & $1.39 \pm 0.03$ & $3.40 \pm 0.02$ & $1.22 \pm 0.02$ & $3.56 \pm 0.30$ & $2.88 \pm 0.12$ \\
\hline C18:1 & $23.78 \pm 0.02$ & $43.37 \pm 0.62$ & $18.81 \pm 0.06$ & $34.42 \pm 0.14$ & $21.6 \pm 0.38$ & $37.56 \pm 0.10$ \\
\hline C18:2 & $13.99 \pm 0.01$ & $18.30 \pm 0.14$ & $63.27 \pm 0.27$ & $58.92 \pm 0.73$ & $43.06 \pm 0.73$ & $39.98 \pm 2.21$ \\
\hline C20:0 & $0.14 \pm 0.01$ & ND & $0.18 \pm 0.01$ & ND & $0.13 \pm 0.01$ & ND \\
\hline $\mathrm{C} 18: 3$ & $52.39 \pm 0.05$ & $33.97 \pm 0.52$ & $0.49 \pm 0.08$ & $0.50 \pm 0.01$ & $21.74 \pm 0.37$ & $11.23 \pm 0.53$ \\
\hline C20:1 & ND & ND & $0.10 \pm 0.01$ & ND & ND & ND \\
\hline $\mathrm{C} 22: 0$ & $0.12 \pm 0.01$ & ND & $0.06 \pm 0.01$ & ND & ND & ND \\
\hline $\mathrm{C} 24: 0$ & $0.09 \pm 0.01$ & ND & $0.09 \pm 0.01$ & ND & $0.09 \pm 0.01$ & ND \\
\hline
\end{tabular}

LO; linseed oil, GO; grape seed oil; SL; structured lipid, ND; not detected.

TABLE 3. Regression coefficents and $p$-values

\begin{tabular}{|c|c|c|c|c|}
\hline \multirow[b]{2}{*}{ Factor } & \multicolumn{2}{|c|}{ Linoleic Acid } & \multicolumn{2}{|c|}{$\alpha$-Linolenic Acid } \\
\hline & Coefficent & $p$-value & Coefficent & $p$-value \\
\hline Intercept & 43.64 & $0.000 \mathrm{a}$ & 15.79 & $0.000 \mathrm{a}$ \\
\hline Substrate molar ratio (L) & 5.01 & $0.000 \mathrm{a}$ & -5.86 & $0.000 \mathrm{a}$ \\
\hline Time (L) & -1.01 & $0.077 b$ & -0.60 & $0.030 \mathrm{a}$ \\
\hline Enzyme (L) & -0.02 & 0.970 & -0.19 & 0.450 \\
\hline Substrate molar ratio $(\mathrm{Q})$ & -2.75 & $0.005 \mathrm{a}$ & 1.99 & $0.000 \mathrm{a}$ \\
\hline
\end{tabular}

L; linear, Q; quadratic, bold values indicate statistically significant factors $\left({ }^{\mathrm{a}} p<0.05 ;{ }^{\mathrm{b}} p<0.10\right)$. 
The $R^{2}$ values of the quadratic model were 0.90 , and 0.98 for linoleic acid and $\alpha$-linolenic acid, respectively. It can be interpreted that the quadratic models were adequate to represent the real relationship between the factors and responses. With respect to $R^{2}$ values, the quadratic model explained $90 \%$ variability in linoleic acid, and $98 \%$ variability in $\alpha$-linolenic acid. The lack of fit values $(p>0.10)$ showed the generated models adequately predicted the responses.

The relationship between the reaction parameters and responses was assessed using the contour plots (Figure 1 and Figure 2).

An increase in the incorporation of linoleic acid was observed with increasing substrate molar ratio up to certain extent (Figures 1A, 1B). The incorporation of linoleic acid appeared to decrease with an increase in the time and enzyme amount (Figure 1C).

The incorporation of $\alpha$-linolenic acid decreased with an increase in the substrate molar ratio (Figure 2A, 2B). An increase in the time and enzyme amount showed a decreasing trend in the incorporation of $\alpha$-linolenic acid (Figure 2C).

With increasing substrate molar ratio, an increase in the linoleic acid incorporation and a decrease in the $\alpha$-linolenic acid incorporation may occur due to an increase linoleic acid and a decrease $\alpha$-linolenic acid in the reaction medium. With increasing time and enzyme amount, a decrease in the incorporation of both fatty acids may be explained by the deficiency of substrate with increasing enzyme amount, and inactivation of enzyme with increasing reaction time.

\subsection{Optimization of the reaction}

The optimal conditions for the targeted responses (linoleic acid: $40 \mathrm{~g} \cdot 100 \mathrm{~g}^{-1}$ and $\alpha$-linolenic acid: $20 \mathrm{~g} \cdot 100 \mathrm{~g}^{-1}$ ) were determined by the optimizer function of Modde 10.1 software. The optimal conditions for the targeted linoleic acid $\left(40 \mathrm{~g} \cdot 100 \mathrm{~g}^{-1}\right)$ and $\alpha$-linolenic acid $\left(20 \mathrm{~g} \cdot 100 \mathrm{~g}^{-1}\right)$ incorporation were $1.4 \mathrm{~mol} / \mathrm{mol}$ for substrate molar ratio, $6.4 \%$ for enzyme amount, and $8.4 \mathrm{~h}$ for time, respectively. The predicted values obtained from the models were $40.2 \mathrm{~g} \cdot 100 \mathrm{~g}^{-1}$ for linoleic acid incorporation, and $20.7 \mathrm{~g} \cdot 100 \mathrm{~g}^{-1}$ for $\alpha$-linolenic acid incorporation, respectively. A batch reaction was carried out at the optimal conditions in order to validate the models of linoleic acid and $\alpha$-linolenic acid incorporation. At the optimal conditions, the SL had $43.1 \mathrm{~g} \cdot 100 \mathrm{~g}^{-1}$ of linoleic acid and $21.7 \mathrm{~g} \cdot 100 \mathrm{~g}^{-1}$ of $\alpha$-linolenic acid. The experimental values were satisfactorily close to the predicted values obtained from the response model equations for the omega fatty acids "in terms of coded factors" $\left(Y_{1}\right.$ and $\left.Y_{2}\right)$.

The impacts of substrate molar ratio, time and enzyme amount were evaluated to optimize the reaction conditions. Substrate molar ratio was reported to be the most significant factor in the synthesis of different SLs by means of a lipase-catalyzed reaction (Khodadadi and Kermasha, 2014). The incorporation of $\alpha$-linolenic acid showed a decreasing trend, whereas the incorporation of linoleic acid exhibited an increasing trend with increasing substrate molar ratio. A higher substrate molar ratio resulted in a higher ratio of omega-6/omega-3 fatty acids. Our findings were comparable with the literature. The enzymatic interesterification of perilla oil with soybean oil or corn oil was carried out to produce SL with a low ratio of omega-6/omega 3 fatty acids, and a higher substrate molar ratio was found to give a higher ratio (Mitra et al., 2010a; Mitra et al., 2010b; Mitra et al., 2012).

Reaction time is a crucial factor for determining optimum reaction conditions to obtain the highest incorporation of targeted fatty acids and to reduce production cost. To reduce production cost, an appropriate shorter reaction time should be chosen (Zhaou et al., 2006). Enzyme amount is an important factor to reduce production cost as well. Up to a certain extent, the incorporation of linoleic acid and $\alpha$-linolenic acid showed a decreasing trend with increasing time and enzyme amount. These results may be related to a shift in the reaction. The hydrolysis of fatty acids may occur rather than the interesterification of fatty acids until the system reached equilibrium (Willis and Marangoni, 1999; Xu et al., 1999).

\subsection{Fatty acid composition of the SL at the optimal conditions}

The fatty acid composition of the SL at the optimal conditions is presented in Table 2. The main fatty acids detected in the SL produced at the optimal conditions were $43 \mathrm{~g} \cdot 100 \mathrm{~g}^{-1}$ of linoleic acid, 22 $\mathrm{g} \cdot 100 \mathrm{~g}^{-1}$ of $\alpha$-linolenic acid, $22 \mathrm{~g} \cdot 100 \mathrm{~g}^{-1}$ of oleic acid, and $10 \mathrm{~g} \cdot 100 \mathrm{~g}^{-1}$ of palmitic acid. The SL contained a higher level of $\alpha$-linolenic acid than the grape seed oil. The $\alpha$-linolenic acid content increased from 0.5 $\mathrm{g} \cdot 100 \mathrm{~g}^{-1}$ (in GO) to $21.7 \mathrm{~g} \cdot 100 \mathrm{~g}^{-1}$ (in SL). The SL included a lower level of linoleic acid compared to the grape seed oil. The linoleic acid content decreased from $63.3 \mathrm{~g} \cdot 100 \mathrm{~g}^{-1}$ (in GO) to $43.1 \mathrm{~g} \cdot 100 \mathrm{~g}^{-1}$ (SL). The SL with a low ratio of omega-6/omega-3 fatty acids was obtained at the optimal conditions. The ratio of omega-6/omega-3 fatty acids in the diet should be about 1 to 4 (Gomez-Candela et al., 2011). The SL produced at the optimal conditions exhibited a comparable value (2) with the recommended intake value. Therefore, it can be interpreted that this product may be used to provide a balanced intake of omega fatty acids.

The SL had linoleic acid $\left(40 \mathrm{~g} \cdot 100 \mathrm{~g}^{-1}\right)$, oleic acid $\left(38 \mathrm{~g} \cdot 100 \mathrm{~g}^{-1}\right), \alpha$-linolenic acid $\left(11 \mathrm{~g} \cdot 100 \mathrm{~g}^{-1}\right)$ and palmitic acid $\left(8 \mathrm{~g} \cdot 100 \mathrm{~g}^{-1}\right)$ at the $s n-2$ position as the 

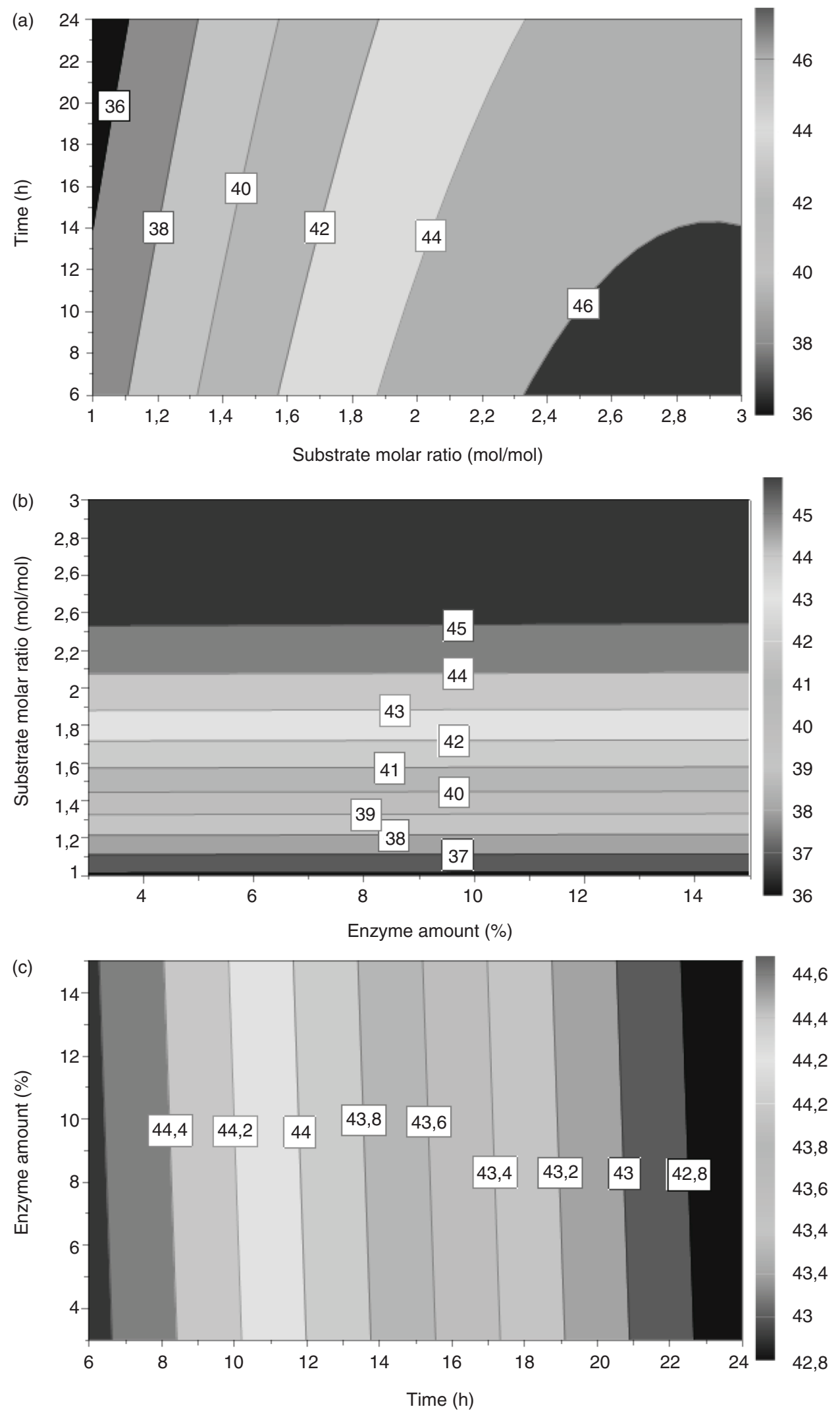

FIGURE 1. Contour plots for the incorporation of linoleic acid. (A) substrate molar ratio-time (B) enzyme amount-substrate molar ratio $(C)$ time-enzyme amount. 
Production of structured lipid with a low omega-6/omega-3 fatty acids ratio by enzymatic interesterification $\bullet 7$
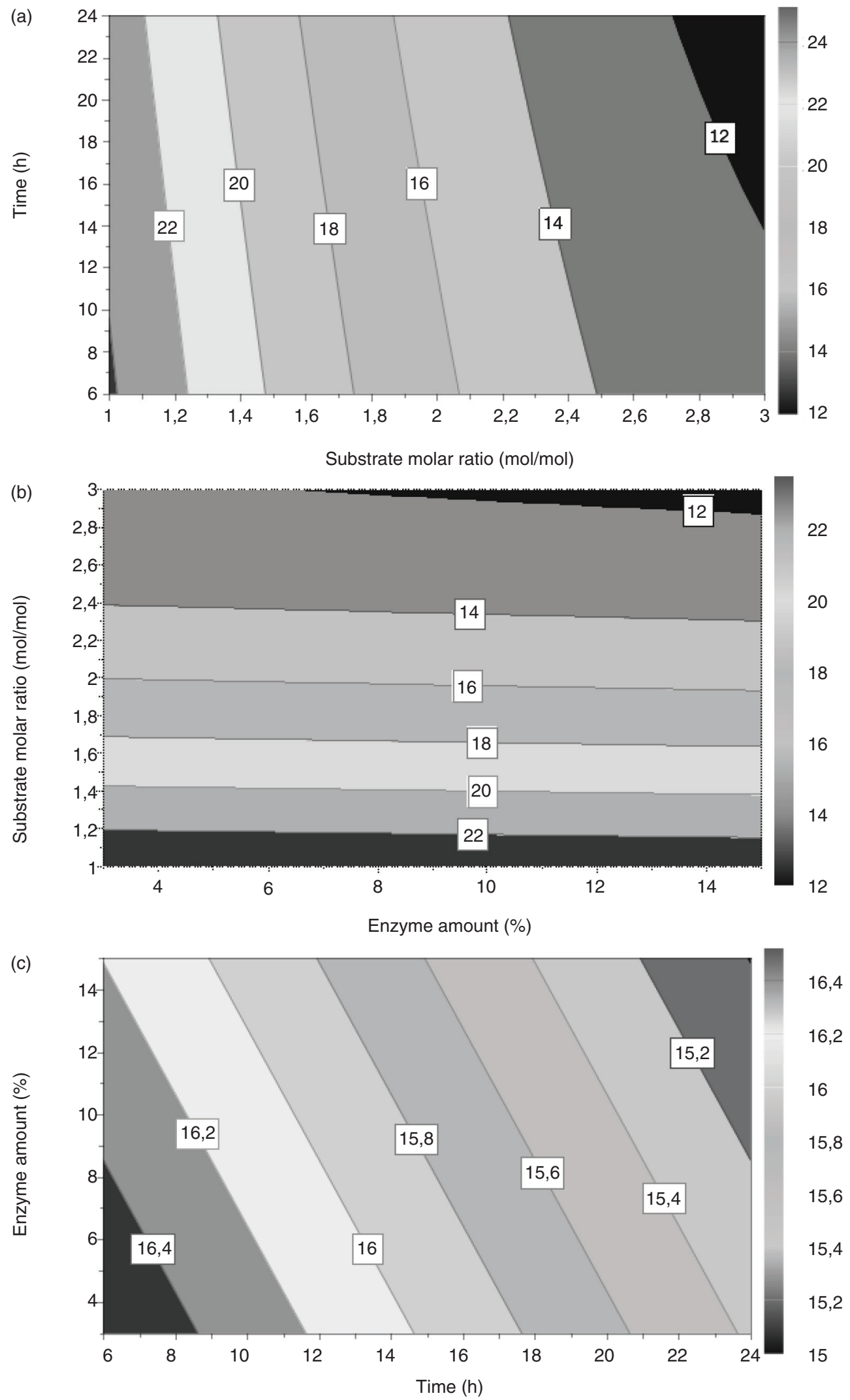

FIgURE 2. Contour plots for the incorporation of $\alpha$-linolenic acid. (A) substrate molar ratio-time (B) enzyme amount-substrate molar ratio $(\mathrm{C})$ time-enzyme amount. 
main fatty acids. At the $s n-2$ position, the SL had a lower level of linoleic acid than the grape seed oil. Furthermore, it contained a lower level of $\alpha$-linolenic acid compared to the linseed oil. These results may be attributed to the $s n-1$ and $s n-3$ specificity of the enzyme used. Linoleic acid and $\alpha$-linolenic acid could be incorporated to the $s n-1$ and $s n-3$ position of the SL.

\subsection{Chemical properties}

The free fatty acid values of the linseed oil, grape seed oil and SL were $1.8,3$, and $0.3 \mathrm{~g} \cdot 100 \mathrm{~g}^{-1}$, respectively. The product exhibited a lower free fatty acid value than the substrates. These findings may be related to the removal of the free fatty acids in the purification step. The peroxide values of the linseed oil, grape seed oil and SL were 7.8, 19.9, and 2.3 meq $\mathrm{O}_{2} \cdot \mathrm{kg}^{-1}$, respectively. The $\mathrm{SL}$ had a lower peroxide value, which may be related to the decomposition of lipid hydroperoxides in the purification step. The iodine value of the product (142) showed a higher value than the grape seed oil (124), whereas its value was lower than the linseed oil (174). The saponification value of the product (192) and substrates (192) were close to each other.

\subsection{Oxidative stability}

The oxidative stability of the SL and SL with antioxidants (BHT, BHA and rosemary extract) was investigated. The peroxide value (PV), TBARS value and $p$-anisidine value ( $p$-AV) of the samples were determined during six days of storage at $60^{\circ} \mathrm{C}$. Fig. 3A presents the changes in the peroxide value (PV) during storage. The PV of the samples showed an increasing trend, except from the $1^{\text {st }}$ to the $2^{\text {nd }}$ day. The PV of the SL reached the value of $14.8 \mathrm{meq}$ $\mathrm{O}_{2} \cdot \mathrm{kg}^{-1}$ at the end of storage. The SL had a significantly higher PV than the SL_ROS during storage ( $\mathrm{p}$ $<0.05)$. The SL BHT and SL BHA showed lower values than the SL. However, a significant difference was observed at day one for both samples and at the sixth day for SL_BHA $(\mathrm{p}<0.05)$.

Figure 3B shows the changes in the $p$-anisidine value $(p-\mathrm{AV})$ during storage. The $p$-AV of the $\mathrm{SL}$ and SL with antioxidants exhibited an increasing trend during storage. The $p$-AVs sharply increased from the very beginning to the $1^{\text {st }}$ day. The SL_ROS had a significantly lower $p$-AV than the SL during storage $(p<0.05)$. The SL_BHA and SL_BHT had lower values than the SL. However, no significant difference was observed $(p>0.05)$, except at the second and sixth days. The SL_BHA showed a significantly lower value than the $\overline{S L}$ at the second and sixth days $(\mathrm{p}<0.05)$.

Figure 3C shows the changes in the TBARS values. The TBARS values of the SL with and without antioxidant slightly changed from day 0 to day 1 .
TBARS values exhibited a sharp increase from the $1^{\text {st }}$ to the $2^{\text {nd }}$ day, whereas a sharp reduction occurred from the $2^{\text {nd }}$ to $4^{\text {th }}$ day, except SL_BHA. The TBARS values slightly changed from the $4^{\text {th }}$ to the $6^{\text {th }}$ day, except SL_BHA, which showed a decreasing trend. The SL_BHA and SL_BHT generally exhibited lower TBARS values than the SL. However, no significant difference was generally observed $(p>0.05)$.

Figure 3D presents changes in the TOTOX values. The TOTOX values of the samples sharply increased from day 0 to day 1 and then slightly changed from the $1^{\text {st }}$ day to the $2^{\text {nd }}$ day. The TOTOX values exhibited an increasing trend from the $2^{\text {nd }}$ to the $6^{\text {th }}$ day. The SL had a higher TOTOX value than the SL with antioxidants during storage. The SL_ROS exhibited a significantly lower value than the SL during storage $(\mathrm{p}<0.05)$. The SL_BHT and SL_BHA had a significantly lower value than the $\mathrm{SL}$ at the first and fourth days $(\mathrm{p}<0.05)$.

Oxidative stability is one of the most important parameters to determine the quality of oils. Oxidation reactions lead to losses in sensorial quality and nutritional value. Primary and secondary oxidation products are formed during lipid oxidation reactions. Hydroperoxides, the primary oxidation products, are decomposed to secondary oxidation products. PV shows primary oxidation products, whereas $p$-AV and TBARS value are used to measure the secondary oxidation products (Kolakowska, 2003). Both PV and $p$-AV of the SL samples increased during storage, revealing that the hydroperoxide formation continued when the hydroperoxides were decomposed to secondary oxidation products. It can be interpreted that the decomposition of hydroperoxides was slower than the formation of hydroperoxides. Firstly, the TBARS value of the samples increased, and then decreased. The TBARS value determines the amount of malonaldehydes, which are not stable compounds. Malonaldehydes are decomposed to organic acids and alcohols. A reduction in the TBARS value may be attributed to the losses of secondary oxidation products via volatilization or decomposition (Maqsood et al., 2010).

The oxidative stability of oils is related to the fatty acid composition and content. Oils containing high levels of unsaturated fatty acids are more susceptible to oxidation reactions. The developed SL including unsaturated fatty acids such as $\alpha$-linolenic acid, linoleic acid and oleic acid, making it susceptible to oxidation. Antioxidants are used to retard lipid oxidation (Kolakowska, 2003). The oxidation study was conducted to improve the oxidative stability of the SL. BHT and BHA (synthetic antioxidants), and rosemary extract (natural antioxidant) were added to the SL. The SL with antioxidants had a lower PV than the SL, revealing that the studied antioxidants could inhibit the formation of primary oxidation products. The SL with antioxidants also exhibited lower $p$-AV and TBARS values than the SL, indicating that the 
Production of structured lipid with a low omega-6/omega- 3 fatty acids ratio by enzymatic interesterification $\bullet 9$
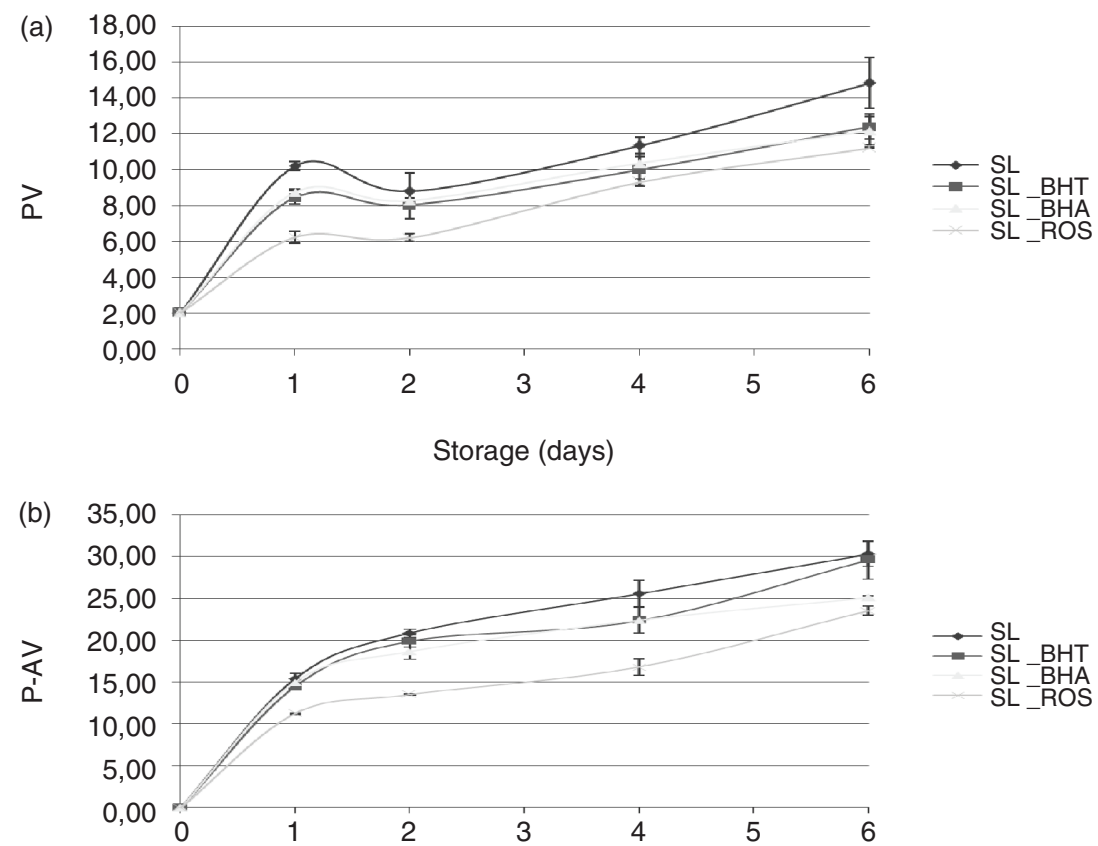

Storage (days)
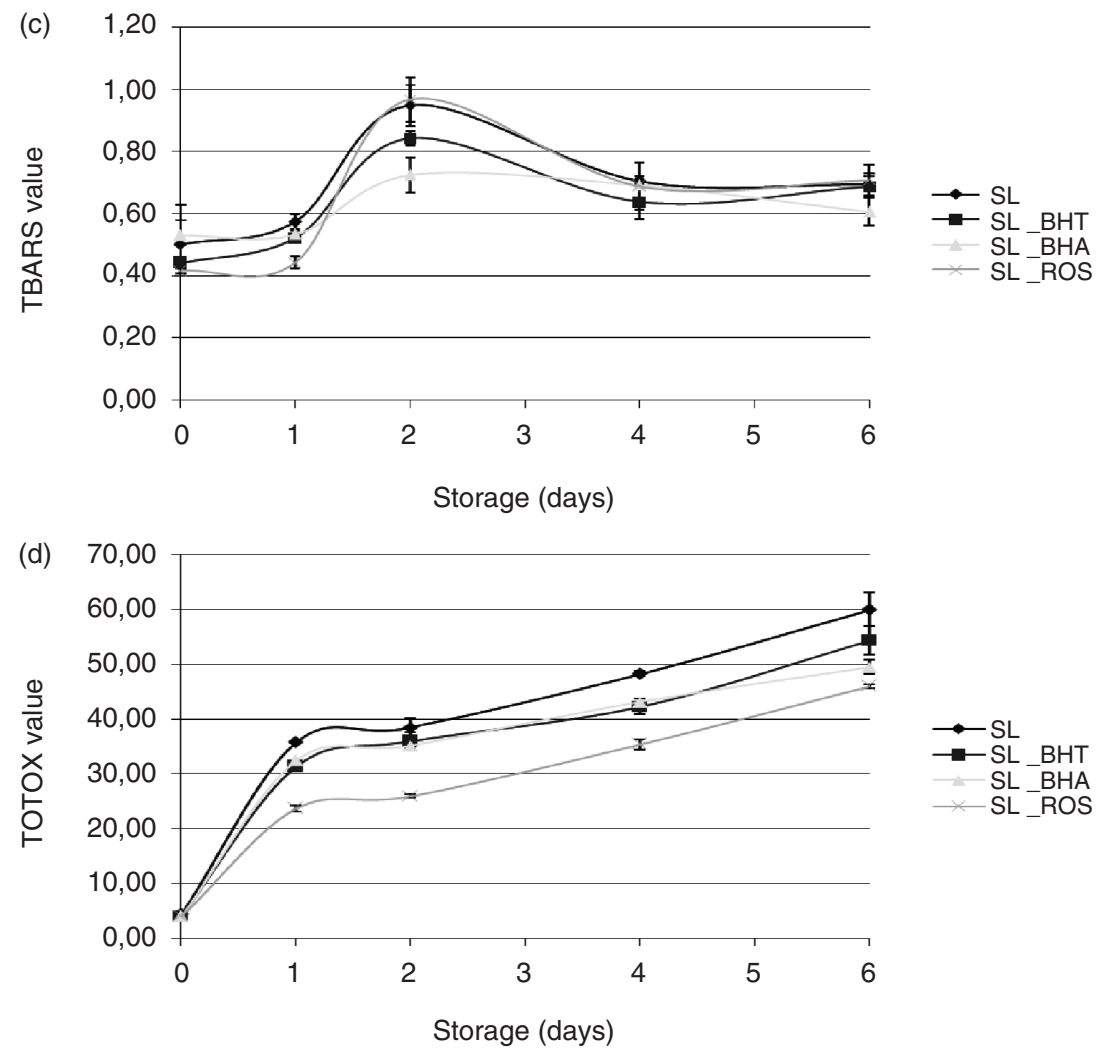

Figure 3. PVs, $p$-AVs, TBARS and TOTOX values of the SL and SL with antioxidants during storage at $60{ }^{\circ} \mathrm{C}$. (A) PVs (B) $p$-AVs

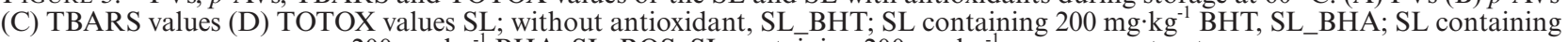
$200 \mathrm{mg} \cdot \mathrm{kg}^{-1}$ BHA, SL_ROS; SL containing $200 \mathrm{mg} \cdot \mathrm{kg}^{-1}$ rosemary extract. 
studied antioxidants could be effective to inhibit secondary oxidation products. Our results were comparable with the literature. It was shown that BHA, BHT and rosemary extract could retard lipid oxidation in edible oils (Zhang et al., 2010). With respect to the results of the oxidation study, it can be interpreted that the rosemary extract was a more effective antioxidant than the synthetic antioxidants. Similar results were reported for plant extracts used in the stabilization of edible oils. Corncob and peanut skin extracts were found to be more effective in retarding primary and secondary oxidation products than the BHT (Sultana et al., 2006 and Taha et al., 2012). The TOTOX value is used to evaluate the total oxidative stability of oils. The SL with antioxidants showed lower TOTOX values than the SL during storage, indicating that the studied antioxidant might improve the oxidative stability of the synthesized SL. The synthetic antioxidants (BHA and BHT) and natural antioxidant (rosemary extract) can be used to improve the oxidative stability of the developed SL. Some publications have supported our findings. The antioxidant efficiency of BHT and rosemary extract on the structured lipid synthesized by enzymatic reactions was determined (Lee et al., 2004; Lee et al., 2006; Mitra et al., 2012).

\section{CONCLUSIONS}

The SL containing linoleic acid and $\alpha$-linolenic acid at a ratio of 2:1 was achieved by the lipase-catalyzed interesterification of linseed and grape seed oils. The oxidative stability of the SL was enhanced with the addition of antioxidants. The produced SL may provide potential health benefits since it had a low ratio of omega-6/omega-3 fatty acids. Intake of the produced SL in the human diet may be proposed as a healthy dietary oil. It may also be utilized in functional food formulations to deliver beneficial fatty acids.

\section{REFERENCES}

Araujo MEMB, Campos PRB, Noso TM, Alberic RM, Silva Cunha IB, Simas RS, Eberlin MN, Oliveria Carvalho P. 2011. Response surface modeling of the production structured lipids from soybean oils using Rhizomucor miehei lipase. Food Chem. 127, 28-33. http://dx.doi.org/10.1016/j. foodchem.2010.12.072

Gomez-Candela C, Lopez LMB, Kohen VL. 2011. Importance of a balanced omega 6/omega 3 ratio for the maintenance of health. Nutritional recommendations. Nutr. Hosp. 6 , 323-329.

Gögüs U, Chris S. 2010. n-3 omega fatty acids: a review of current knowledge. Int. J. Food Sci. Technol. 45, 417-436. https://doi.org/10.1111/j.1365-2621.2009.02151.x

Hamam F, Shahidi F. 2005a. Structured lipids from highlaurate canola oil and long chain omega-3 fatty acids. $J$. Am. Oil Chem. Soc. 82, 731-736. https://doi.org/10.1007/ s11746-005-1135-9

Hamam F, Shahidi F. 2005b. Enzymatic incorporation of capric acid into single cell oil rich in docosahexaenoic acid and docosapentaenoic acid and oxidative stability of the resultant structured lipid. Food Chem. 91, 583-591. https://doi. org/10.1016/j.foodchem.2004.05.024
Hita E, Robles A, Camacho B, Ramirez A, Esteban L, Jimenez MJ, Munio MM, Gonzalez PA, Molina E. 2007. Production of structured triacylglycerols (STAG) rich in docosahexanoic acid (DHA) in position 2 by acidolysis of tuna catalyzed by lipases. Process Biochem. 42, 415-422. http://dx.doi.org/10.1016/j.procbio.2006.09.023

Khodadadi M, Kermasha S. 2014. Modeling lipase-catalyzed interesterification of flaxseed oil and tricaprylin for the synthesized structured lipids. J. Mol. Catal. B Enzym. 102, 33-40. https://doi.org/10.1016/j.molcatb.2014.01.011

Kolakowska, A. 2003. Lipid oxidation in food systems. Sikorski ZE and Kolakowska A (Ed). In: Chemical and Functional Properties of Food Lipids. CRC Press LLC, Boca Raton, FL, USA. pp. 19-20.

Lee JH, Shin JA, Lee JH, Lee, TI. 2004. Production of lipase-catalyzed structured lipids from safflower oil with conjugated linoleic acid and oxidation studies with rosemary extract. Food Res. Int. 37, 967-974. https://doi.org/10.1016/j. foodres.2004.06.005

Lee JH, Lee KT, Akoh CC, Chung SK, Kim MR. 2006. Antioxidant evaluation and oxidative stability of structured lipids from extra virgin olive oil and conjugated linoleic acid. J. Agric. and Food Chem. 54, 5416-5421. http:// dx.doi.org/10.1021/jf0603735

Maqsood S, Benjakul, S. 2010. Comparative studies of four phenolic compounds on in vitro antioxidant activity and the preventive effect on lipid oxidation of fish oil emulsion and fish mince. Food Chem. 119, 123-132. http://dx.doi. org/10.1016/j.foodchem.2009.06.004

Mitra K, Lee JH, Lee KT, Kim SA. 2010a. Production tactic and physiochemical properties of low w6/w3 ratio structured lipid synthesised from perilla and soybean oil. Int. J. Food Sci. Technol. 45, 1321-1329. https://doi. org/10.1111/j.1365-2621.2009.02132.x

Mitra K, Kim SA, Lee JH, Choi SW, Lee KT. 2010b. Production and characterization of $\alpha$-linolenic acid enriched structured lipids from lipase-catalyzed interesterification. Food Sci. Bioctechnol. 19, 57-62. https://doi.org/10.1007/ s10068-010-0008-Z

Mitra K, Shin JA, Lee JH, Kim SA, Hong ST, Sung CK, Xue CL, Le KT. 2012. Studies of reaction variables for lipase-catalyzed production of alpha-linolenic acid enriched structured lipid and oxidative stability with antioxidant. J. Food Sci. 77, C39-C45. http://dx.doi. org/10.1111/j.1750-3841.2011.02464.x

Rao R, Manohar B, Sambaiah K, Lokesh BR. 2002. Enzymatic acidolysis in hexane to produce n-3 or n-6 FA-enriched structured lipids from coconut oil: Optimization of reactions by response surface methodology. J. Am. Oil Chem. Soc. 79, 895-890. https://doi.org/10.1007/ s11746-002-0574-7

Sharma M, Rastogi NK, Lokesh BR. 2009. Synthesis of structured lipid with balanced omega-3: Omega- 6 ratio by lipase-catalyzed acidolysis reaction: Optimization of reaction using response surface methodology. Process Biochem. 44, 1284-1288. http://dx.doi.org/10.1016/j. procbio.2009.07.005

Shimada Y, Suenaga M, Sugihara A, Nakai S, Tominiga Y. 1999. Continuous production of structured lipid containing $\gamma$-linolenic and caprylic acids by immobilized Rhizopus delemar lipase. J. Am. Oil Chem. Soc. 76, 189-193. https:// doi.org/10.1007/s11746-999-0217-X

Simopoulos AP. 2008. The importance of the omega-6/omega-3 fatty acid ratio in cardiovascular disease and other chronic diseases. Exp. Biol. Med. 233, 674-688.

Sultana B, Anwar F, Przybylski R. 2007. Antioxidant potential of Carnob extract for stabilization corn oil subjected to microwave heating, Food Chem. 104, 997-1005. https://doi. org/10.1016/j.foodchem.2006.12.061

Taha FS, Wagdy SM, Singer FA. 2012. Comparision between antioxidant activities of phenolic extracts from different parts of peanut. Life Sci. J. $9207-215$.

Xu X, Mu H, Skands ARH, Hoy CE, Adler-Nissen J. 1999. Parameters affecting diacylglycerol formation during the production of specific-structured lipids by lipase-catalyzed reaction. J. Am. Oil Chem. Soc. 76, 175-181. 
Production of structured lipid with a low omega-6/omega-3 fatty acids ratio by enzymatic interesterification 11

Willis WM, Marangoni AG. 1999. Assesment of lipase- and chemically catalyzed lipid modification strategies for the production of structured lipid. J. Am. Oil Chem. Soc. 76 , $443-450$.

Yang D, Gan LJ, Shin JA, Kim S, Hong ST, Park SH. 2013. Antioxidative activities of ginkgo biloba extract on oil/water emulsion system prepared from an enzymatically modified lipid containing alpha-linolenic acid. J. Food Sci. 78, C43C49. http://dx.doi.org/10.1111/j.1750-3841.2012.03010.x
Zhang Y, Yang L, Zu Y, Chen X, Wang F, Liu F. 2010. Oxidative stability of sunflower oil supplemented with carnosic acid compared with synthetic antioxidants during accelerated storage. Food Chem. 118, 656-662. https://doi. org/10.1016/j.foodchem.2009.05.038

Zhaou H, Lu Z, Lu F, Bie X, Liu Z, Zeng X. 2006. Lipase catalyzed acidolysis of lard with caprylic acid to produce structured lipid. Int. J. Food Sci. Technol. 41, 1027-1032. https:// doi.org/10.1111/j.1365-2621.2006.01160.x 